\title{
Species diversity of fungi on damaged branches and leaves of ashes (Fraxinus spp.) in different types of stands in Slovakia
}

\author{
Katarína Pastirčáková1* ${ }^{*}$ Helena Ivanová ${ }^{1}$, Martin Pastirčák ${ }^{2}$ \\ ${ }^{1}$ Slovak Academy of Sciences, Institute of Forest Ecology, Branch for Woody Plant Biology, Akademická 2, \\ SK - 94901 Nitra, Slovak Republic \\ ${ }^{2}$ National Agricultural and Food Centre, Research Institute of Plant Production, Bratislavská cesta 122, \\ SK-921 68 Pieštany, Slovak Republic
}

\begin{abstract}
The diversity of fungi on branches and leaves of ashes (Fraxinus angustifolia, F. excelsior, F. ornus) in Slovakia was studied. Symptomatic material collected in Slovakia during the period of 2013 to 2017 and herbarium specimens previously collected were examined. In total, 30 fungal taxa (15 Deuteromycetes, 14 Ascomycetes and one Basidiomycetes) were recorded. Twenty-three of them have never been recorded on ashes in the country. The most frequently occurring fungi were Hymenoscyphus fraxineus (anamorph Chalara fraxinea) that causes necrosis of shoots and branches, and Phyllactinia fraxini, a foliar pathogen that causes powdery mildew disease. Fungal diversity on ashes growing in different types of stands was compared. Species richness was the greatest in seed orchards (20 fungal taxa) compared to private gardens, which contained the lowest (two fungal taxa). Species diversity in forest stands comprised 18 fungal taxa and the urban greenery was represented by 10 fungal taxa. Nine fungal taxa were recorded in tree alley along the road. The widest fungal species spectrum was recorded on F. excelsior.
\end{abstract}

Key words: mycobiota; ash dieback; plant pathogens; saprophytes

Editor: Andrej Kunca

\section{Introduction}

Three native ash species, European ash (Fraxinus excelsior L.), narrow-leafed ash ( $F$. angustifolia Vahl) and manna ash (F.ornus L.) occur on the territory of Slovakia. Ashes compose an important part of Slovak forests, and they are often planted as ornamental trees in the urban greenery. Although Fraxinus has relatively low representation in our forests (1.6\%), ash wood remains industrially important (Anonymous 2015). This woody plant is sensitive to climatic fluctuations, especially to late frosts.

In the 1990s, an extensive outbreak of ash dieback occurred in north-eastern Europe. Due to the spread of the causal agent, Hymenoscyphus fraxineus (anamorph Chalara fraxinea) in recent years, ash trees of all ages are severely damaged across Europe. Some of the major symptoms of the disease are leaf necrosis, premature leaf abscission, and necrosis of the bark, cambium, and phloem, leading to the dying of shoots and branches. This disease causes a widespread mortality of ash trees. Thus, ash dieback threatens the existence of Fraxinus on the European continent (Vasaitis \& Enderle 2017). Fraxinus excelsior has been registered in the Sweden's Red list of plants since 2010. Hymenoscyphus fraxineus attacks mainly $F$. excelsior and $F$. angustifolia. The following susceptible hosts have also been recorded: black ( $F$. nigra Marshall), green ( $F$. pennsylvanica Marshall), white $(F$. americana L.), Manchurian (F. mandshurica Rupr.), manna (F.ornus) and Chinese (F. chinensis subsp. rhynchophylla (Hance) E. Murray) ash trees (Drenkhan \& Hanso 2010; Kirisits \& Schwanda 2015; Gross \& Han 2015). In Slovakia, the first evidence of the disease occurred more than 10 years ago (Kunca et al. 2006) and the identity of the fungal pathogen on F. excelsior and $F$. angustifolia was confirmed by molecular techniques (Adamčíková et al. 2015; Kádasi-Horáková et al. 2017). Due to the massive dieback of ashes at the present time, forest managers prefer culling or completely eliminating whole ash groups (Longauerová et al. 2017).

Although $H$. fraxineus is considered to be the main cause of dying ash trees, many other fungal genera (Cytospora, Diplodia, Fusarium, Phomopsis) colonizing ash shoots and branches are associated with their damage (Griffith \& Boddy 1988; Przybyl 2002; Kowalski \& Łukomska 2005; Kowalski \& Czekaj 2010; Kowalski 
et al. 2016). In Slovakia, previous authors (Juhásová et al. 2003, 2004) recorded 10 fungal taxa on ashes during the assessment of the status of woody plant health in urban greenery. There has been no further data on the detailed composition of mycobiota of ashes in Slovakia recorded since the first appearance of the ash dieback in the country.

The aim of the present study was to determine species diversity of fungi colonizing and damaging branches and leaves of our native Fraxinus species growing in different types of stands in Slovakia.

\section{Material and methods}

From 2013 to 2017, symptomatic ash branches and leaves (F. angustifolia, F. excelsior, F. ornus) were collected at selected localities in the urban and extra-urban vegetation of Slovakia. Samples (one sample was material taken from one tree) were examined by means of a stereo microscope (Olympus SZ61, Tokyo, Japan) and standard light microscope (Olympus BX51, Tokyo, Japan). Fungi that have formed reproductive structures on the studied material were identified on the basis of their morphological characteristics using taxonomic manuals for fungi (Arx \& Müller 1954; Dennis 1978; Sutton 1980; Sivanesan 1984; Ellis \& Ellis 1985; Kiffer \& Morelet 2000).

In addition to the direct identification of mycobiota on the examined material, an in vitro cultivation on artificial culture media was used to detect the presence of microscopic fungi. The selected material was surface-sterilized using $70 \%$ ethanol for $1 \mathrm{~min}, 2 \%$ sodium hypochlorite for $10 \mathrm{~min}$, flushed with sterile distilled water, and then cultured on culture medium (potato-dextrose agar). The cultures were incubated in the dark at $22 \pm 2{ }^{\circ} \mathrm{C}$ in a climate chamber MLR-351H (Sanyo, Japan). Isolated fungi were identified based on their cultural and morphological characteristics using the above literature.

In order to find out the spectrum of fungi previously found on Fraxinus spp. in Slovakia in the past (before 2013), herbarium specimens deposited in the Plant Pathology Herbarium (herbarium code: NR) of the Institute of Forest Ecology SAS Zvolen, Branch for Woody Plant Biology in Nitra were examined and revised. Herbarium specimens were collected by Gabriela Juhásová after 1980.

Based on the sampling sites, the samples were categorized according to the type of stand (A - tree alley along the road, $\mathrm{F}$ - forest, $\mathrm{G}$ - private gardens, $\mathrm{O}$ - seed orchard and arboretum, $\mathrm{P}$ - public parks and inter-block greenery). The frequency (\%) of occurrence of the fungal taxa was calculated.

\section{Results}

In our study, we focused on identifying microscopic fungi associated with damage of ash leaves and branches, as well as withering of ashes in forests, orchards and urban vegetation. A total of 287 samples were analysed. Samples were collected from branches and leaves of Fraxinus spp. growing at 82 sampling sites in different parts of Slovakia (Fig. 1). The sampling sites represented different types of ash stands with different levels of management (42 public parks and inter-block greenery, 18 forest stands, 14 tree alleys, 4 seed orchards including one arboretum, and 4 private gardens).

A total of 30 fungal taxa (15 Deuteromycetes, 14 Ascomycetes, and 1 Basidiomycetes) were identified on branches and leaves of $F$. angustifolia, F. excelsior, and $F$. ornus. The data overview and the frequency of the recorded fungi was given in Table 1. Twenty-three of the fungal taxa

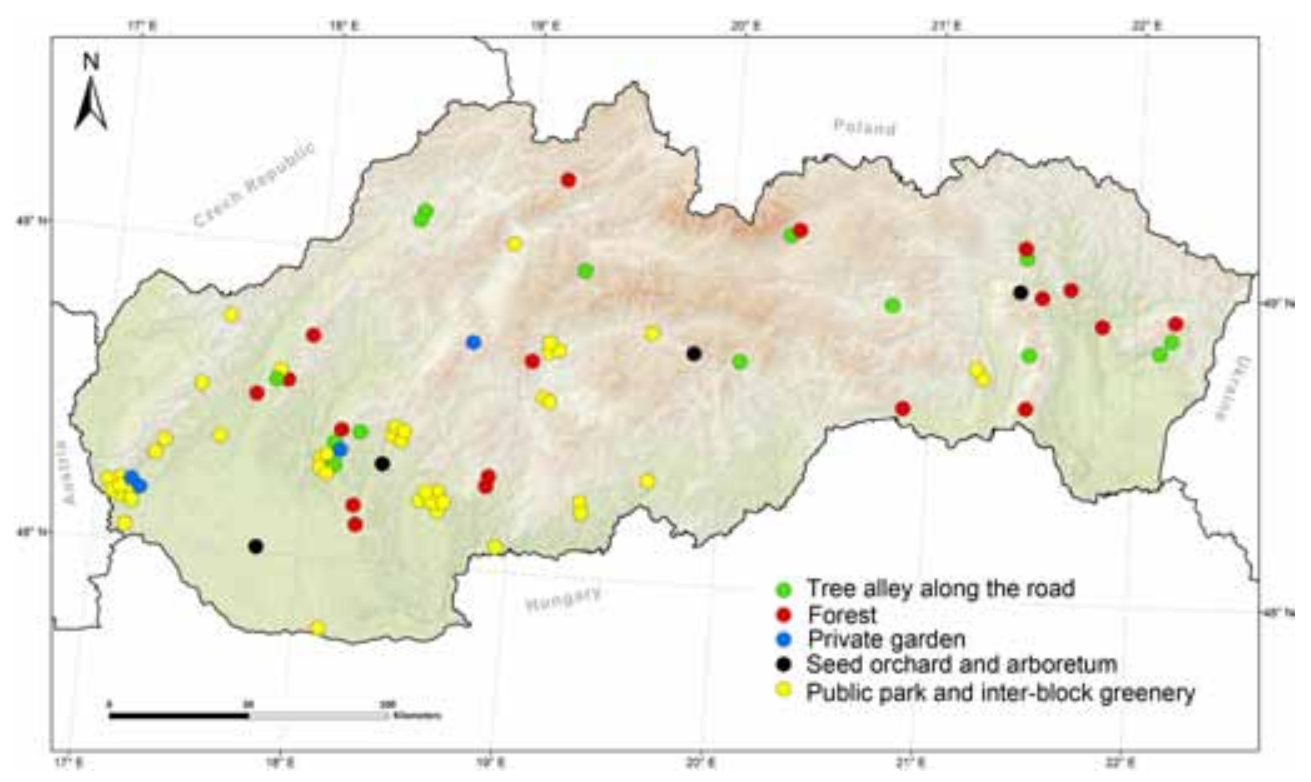

Fig. 1. Localization of sampling sites in Slovakia. 
had never been recorded on Fraxinus in Slovakia. The novel taxa were marked with an asterisk (*) in Table 1. Fifteen species, namely Botryosphaeria dothidea, Camarosporium orni, Coniothyrium fuckelii, Cryptosphaeria eunomia, Cucurbitaria obducens, Diaporthe eres, Didymosphaeria decolorans, Diplodia fraxini, Discula fraxinea, Dothiorella sarmentorum, Gloeosporidiella turgida, Hypoxylon fraxinophilum, Hysterographium fraxini, Immotthia atrograna, and Microdiplodia fraxini, were not included in the checklist of fungi of Slovakia (Lizoň \& Bacigálová 1998). The present paper documents the occurrence of these fungal species for the first time in Slovakia.

Under the in vitro conditions, the following 12 fungal taxa were isolated from ash shoots and branches: Alternaria alternata, Botryosphaeria dothidea, Botrytis cinerea, Camarosporium orni, Cladosporium cladosporioides, Clonostachys rosea, Coniothyrium fuckelii, Diplodia fraxini, Dothiorella sarmentorum, Fusarium sp., Phomopsis sp., and Sordaria sp.

Species richness (20 fungal taxa) was the greatest in seed orchards (monoculture plots). There were 18 fungal species found on ashes growing in forest stands (both single-tree species and mixed-tree species forest plots), 10 species in public parks and inter-block greenery, nine species in tree alleys along the road, and two species in private gardens (Fig. 2). The most common fungi occurring in all types of ash stands were Hymenoscyphus fraxineus causing necrosis of ash shoots and branches, and Phyllactinia fraxini causing powdery mildews. Hymenoscyphus fraxineus occurred very sporadically in urban ash plantations, presumably due to low quality of maintenance of a stand. The occurrence of the major pathogen, $H$. fraxineus, in the ash stands lead to the progressive withering and death of the trees. Rarely (only in one type of stand), 16 fungal taxa were recorded. There were 28 fungal taxa that colonized the bark and branches and 4 taxa were found on leaves, while two of them $(H$. fraxineus and Phomopsis sp.) occurred on the bark, branches, and the leaves. The list of fungi found on three species of Fraxinus in Slovakia is shown in Table 2. The widest fungal species spectrum was recorded on F. excelsior. The results showed that, in necrotic ash tissue, numerous fungi may occur, although only a few species are very frequent. Known plant pathogenic fungi present in a stand of dead ashes, such as: Botryosphaeria dothidea, Cytospora sp., Diaporthe eres, Diplodiafraxini, Gibberellabaccata, and Tubercularia vulgaris, may represent a noticeable threat to young or stressed and weakened ash trees. These fungi

Table 1. The frequency of occurrence of fungal taxa on Fraxinus spp. in different type of stands in Slovakia.

\begin{tabular}{|c|c|c|c|c|c|c|}
\hline Fungus & Mode of life & Substrate & $\begin{array}{c}\text { Number } \\
\text { of sampling sites }\end{array}$ & $\begin{array}{c}\text { Number } \\
\text { of samples }^{\mathrm{b}}\end{array}$ & $\begin{array}{c}\text { Frequencyc }^{c} \\
{[\%]}\end{array}$ & Type of stand ${ }^{d}$ \\
\hline \multicolumn{7}{|l|}{ Ascomycetes } \\
\hline${ }^{*}$ Botryosphaeria dothidea (Moug.) Ces. \& De Not. & parasite & branch & 1 & 1 & 0.3 & 0 \\
\hline * Cryptosphaeria eunomia (Fr.) Fuckel & parasite & branch & 3 & 4 & 1.4 & $\mathrm{~A}, \mathrm{~F}, \mathrm{O}$ \\
\hline *Cucurbitaria obducens (Schumach.) Petr. & saprophyte & branch & 3 & 3 & 1.0 & $\mathrm{~A}, \mathrm{~F}$ \\
\hline *Diaporthe eres Nitschke & parasite & branch & 2 & 2 & 0.7 & F,P \\
\hline * Didymosphaeria decolorans Rehm & saprophyte & branch & 1 & 3 & 1.0 & $\mathrm{~F}$ \\
\hline Gibberella baccata (Wallr.) Sacc. & parasite & branch & 1 & 1 & 0.3 & $P$ \\
\hline $\begin{array}{l}\text { Hymenoscyphus fraxineus (T. Kowalski) Baral, Queloz \& Hosoya; } \\
\text { anamorph Chalara fraxinea T. Kowalski }\end{array}$ & $\begin{array}{l}\text { saprophyte, } \\
\text { parasite }\end{array}$ & leaf, branch & 25 & 120 & 41.8 & $\mathrm{~A}, \mathrm{~F}, \mathrm{G}, \mathrm{O}, \mathrm{P}$ \\
\hline * Hypoxylon fraxinophilum Pouzar & saprophyte & branch & 1 & 8 & 2.8 & $\mathrm{~F}$ \\
\hline *Hysterographium fraxini(Pers.) De Not. & saprophyte & branch & 3 & 9 & 3.1 & $\mathrm{~A}, \mathrm{~F}, \mathrm{O}$ \\
\hline *Immotthia atrograna (Cooke \& Ellis) M.E. Barr & mycoparasite & branch & 1 & 1 & 0.3 & $\mathrm{~F}$ \\
\hline $\begin{array}{l}\text { Neonectria ditissima (Tul. \& C. Tul.) Samuels \& Rossman } \\
\text { (= Nectria galligena Bres.) }\end{array}$ & saprophyte & branch & 3 & 6 & 2.1 & $\mathrm{~F}, \mathrm{O}, \mathrm{P}$ \\
\hline Phyllactinia fraxini(DC.) Fuss (=P. guttata (Wallr.) Lév.) & parasite & leaf & 41 & 73 & 25.4 & $\mathrm{~A}, \mathrm{~F}, \mathrm{G}, \mathrm{O}, \mathrm{P}$ \\
\hline *Sordariasp. & saprophyte & branch & 1 & 2 & 0.7 & 0 \\
\hline${ }^{*}$ Xylaria longipes Nitschke & saprophyte & branch & 1 & 1 & 0.3 & $\mathrm{~F}$ \\
\hline \multicolumn{7}{|l|}{ Basidiomycetes } \\
\hline *Trametes versicolor (L.) Lloyd & saprophyte & branch & 1 & 1 & 0.3 & $\mathrm{P}$ \\
\hline \multicolumn{7}{|l|}{ Deuteromycetes } \\
\hline *Alternaria alternata (Fr.) Keissl. & endophyte & branch & 1 & 2 & 0.7 & 0 \\
\hline *Botrytis cinerea Pers. & endophyte & branch & 1 & 1 & 0.3 & $\mathrm{O}$ \\
\hline *Camarosporium orni Henn. & saprophyte & branch & 3 & 5 & 1.7 & $\mathrm{~A}, \mathrm{~F}, \mathrm{O}$ \\
\hline${ }^{*}$ Cladosporium cladosporioides (Fresen.) G.A. de Vries & endophyte & branch & 1 & 1 & 0.3 & 0 \\
\hline${ }^{*}$ Clonostachys rosea (Link) Schroers, Samuels, Seifert \& W. Gams & mycoparasite & branch & 1 & 1 & 0.3 & 0 \\
\hline *Coniothyrium fuckelii Sacc. & saprophyte & branch & 1 & 1 & 0.3 & $\mathrm{O}$ \\
\hline${ }^{*}$ Cytospora sp. & parasite & branch & 5 & 15 & 5.2 & $\mathrm{~A}, \mathrm{~F}, \mathrm{O}, \mathrm{P}$ \\
\hline * Diplodia fraxini(Fr.) Fr. & parasite & branch & 5 & 9 & 3.1 & $\mathrm{~A}, \mathrm{~F}, \mathrm{O}, \mathrm{P}$ \\
\hline * Discula fraxinea (Peck) Redlin \& Stack & parasite & leaf & 1 & 1 & 0.3 & $\mathrm{~F}$ \\
\hline * Dothiorella sarmentorum (Fr.) A.J.L. Phillips, A. Alves \& J. Luque & parasite & branch & 1 & 2 & 0.7 & $\mathrm{O}$ \\
\hline Fusarium sp. & parasite & branch & 1 & 1 & 0.3 & $\mathrm{O}$ \\
\hline *Gloeosporidiella turgida (Berk. \& Broome) B. Sutton & parasite & branch & 3 & 3 & 1.0 & $\mathrm{~F}, \mathrm{O}, \mathrm{P}$ \\
\hline *Microdiplodia fraxini Died. & saprophyte & branch & 1 & 1 & 0.3 & $\mathrm{~F}$ \\
\hline Phomopsis sp. (=Phyllosticta fraxinicola Sacc.) & parasite & leaf, branch & 6 & 7 & 2.4 & $\mathrm{~F}, \mathrm{O}, \mathrm{P}$ \\
\hline Tubercularia vulgaris Tode & parasite & branch & 2 & 2 & 0.7 & $\mathrm{~A}, \mathrm{O}$ \\
\hline
\end{tabular}

${ }^{\text {a Number of sampling sites on which the occurrence of identified fungi was recorded. }}$

${ }^{\mathrm{b}}$ Number of samples in which the identified fungi were present (out of 287 examined samples).

'Frequency of the occurrence of fungi in total collection of 287 examined samples.

${ }^{\mathrm{d}} \mathrm{A}$ - tree alley along the road, $\mathrm{F}$ - forest, $\mathrm{G}$ - private gardens, $\mathrm{O}$ - seed orchard and arboretum, $\mathrm{P}$ - public parks and inter-block greenery.

* Fungal taxa not recorded on Fraxinus to date in the country.

The name on the original herbarium label is indicated in bracket. 


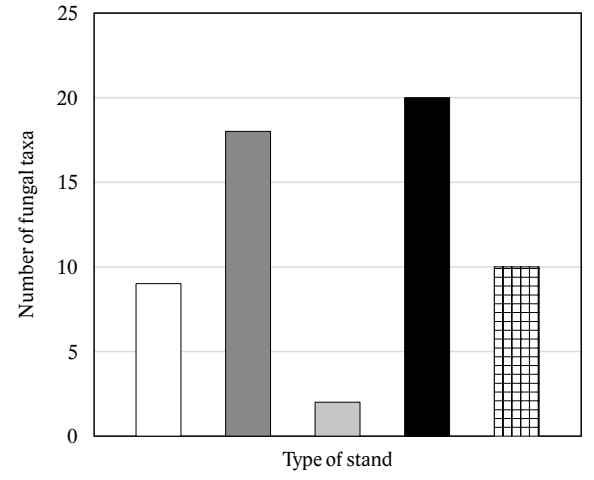

$\square$ Tree alley along the roa

$\square$ Forest stand

$\square$ Private garden

- Seed orchard and

$\boxplus \begin{aligned} & \text { Public park } \\ & \text { and inter-block }\end{aligned}$ greenery

Fig. 2. Number of fungal taxa by type of ash stand in Slovakia.

possess a broad host spectrum that also places other tree species at risk of disease.
The fungi that we recorded on ash branches and leaves represent the taxa with different heterotrophy, such as saprophytes feeding on the dead or decaying substrates (e.g. Cucurbitaria, Didymosphaeria, Hymenoscyphus, Hypoxylon, Hysterographium, Neonectria, Sordaria, Trametes, Xylaria), parasites that prefer to colonize living plant tissues (e.g. Chalara, Diplodia, Gloeosporidiella, Phomopsis, Phyllactinia, Tubercularia), and endophytes (Alternaria, Botrytis, Cladosporium). Also mycoparasitic fungi, Immotthia atrograna parasitic on Hypoxylon fraxinophilum and Clonostachys rosea parasitic on Sordaria sp., were recorded on dead branches of F. excelsior.

Fungal specimens obtained during this study were preserved as a collection of herbarium materials (NR), as a data source for studying the geographical distribution of fungi and as the source of DNA of the fungi for molecular taxonomic analyses.

Table 2. The spectrum of fungi found on Fraxinus spp. in Slovakia.

\begin{tabular}{|c|c|c|}
\hline Host & Fungus & Location of sampling sites \\
\hline \multirow{14}{*}{ F. angustifolia } & Alternaria alternata & Trstice ${ }^{c}$ \\
\hline & Botryosphaeria dothidea & Trstice ${ }^{c}$ \\
\hline & Botrytis cinerea & Trstice ${ }^{\mathrm{c}}$ \\
\hline & Camarosporium orni & Trstice ${ }^{c}$ \\
\hline & Cladosporium cladosporioides & Trstice ${ }^{c}$ \\
\hline & Coniothyrium fuckelii & Trstice ${ }^{c}$ \\
\hline & Diplodia fraxini & Trstice ${ }^{c}$ \\
\hline & Dothiorella sarmentorum & Trstice ${ }^{c}$ \\
\hline & Fusarium sp. & Trstice $^{c}$ \\
\hline & Hymenoscyphus fraxineus & Trstice $^{\mathrm{b}}$, Vieska nad Žitavou ${ }^{\mathrm{b}}$ \\
\hline & Hysterographium fraxini & Trstice ${ }^{\mathrm{b}}$ \\
\hline & Phomopsis sp. & Trstice $^{c}$ \\
\hline & Phyllactinia fraxini & Bratislava ${ }^{\mathrm{a}, \mathrm{b}}$, Nitra $^{\mathrm{a}, \mathrm{b}}$ \\
\hline & Sordaria sp. & Trstice \\
\hline \multirow{29}{*}{ F.excelsior } & Alternaria alternata & Trstice $^{c}$ \\
\hline & Camarosporium orni & Považská Tepláb, Stará Lesnáb \\
\hline & Clonostachys rosea & Trstice $^{c}$ \\
\hline & Cryptosphaeria eunomia & Kukováb, Podhorany (Nitra District) ${ }^{b}$, Vieska nad Žitavou ${ }^{b}$ \\
\hline & Cucurbitaria obducens & Kukováb, Podhorany (Nitra District) ${ }^{b}$, Stará Lesná $^{b}$ \\
\hline & Cytosporasp. & Kukováb ${ }^{b}$ Nitra $^{b}$, Pieštany $^{b}$, Podhorany (Nitra District) ${ }^{b}$, Stará Lesnáb $^{b}$ \\
\hline & Diaporthe eres & Nitrab $^{b}$ Stará Lesnáb \\
\hline & Didymosphaeria decolorans & Kukováb \\
\hline & Diplodia fraxini & Kostolany pod Tríbečom ${ }^{b}$, Kukováb , Nitra ${ }^{b}$, Pieštany ${ }^{b}$ \\
\hline & Discula fraxinea & Kukováb \\
\hline & Dothiorella sarmentorum & Trstice $^{c}$ \\
\hline & Gibberella baccata & Nitra $^{\mathrm{a}}$ \\
\hline & Gloeosporidiella turgida & Kukováb Trstice $^{\mathrm{b}}$ \\
\hline & & Badín $^{\mathrm{b}}$, Brekov $^{\mathrm{b}}$, Černík ${ }^{\mathrm{b}}$, Hermanovce nad Toplou ${ }^{\mathrm{b}}$, Hôrka nad Váhom ${ }^{\mathrm{b}}$, Kukováb $^{\mathrm{b}}$ Kvakovce $^{\mathrm{b}}$, Ladzany $^{\mathrm{b}}$, \\
\hline & Hymenoscyphus fraxineus & Lipníky ${ }^{\mathrm{b}}$, Podsucháb ${ }^{\text {, Poruba pod Vihorlatom }}$, Považská Tepláb, Remetské Hámre ${ }^{b}$, Štitáre ${ }^{b}$, Topolčianky ${ }^{b}$, \\
\hline & & Trstice ${ }^{b}$, Turňa nad Bodvou ${ }^{\mathrm{b}}$, Úlany nad Žitavou ${ }^{\mathrm{b}}$, Vieska nad Žitavou ${ }^{\mathrm{b}}$, Zázriváb $^{\mathrm{b}}$ Z Zbojskáb \\
\hline & Hypoxylon fraxinophilum & Kukováb \\
\hline & Hysterographium fraxini & Kukováb, Stará Lesnáb ${ }^{\text {Trstice }}{ }^{b}$ \\
\hline & Immotthia atrograna & Kukováb \\
\hline & Microdiplodia fraxini & Stará Lesnáb \\
\hline & Neonectria ditissima & Kostolany pod Tríbečom ${ }^{b}$ Kukováb \\
\hline & & Banská Bystrica ${ }^{\mathrm{a}}$, Bratislava ${ }^{\mathrm{a}, \mathrm{b}}$, Brezno $^{\mathrm{b}}$, Handlováa $^{\mathrm{a}}$, Herlany ${ }^{\mathrm{a}}$, Horné Lefantovce $^{\mathrm{a}}$, Komárno $^{\mathrm{a}}$, Košice $^{\mathrm{a}}$, \\
\hline & Phyllactinia fraxini & Levice $^{\mathrm{a}}$, Modra $^{\mathrm{a}}$, Murán̆ $^{\mathrm{b}}$, Myjava $^{\mathrm{a}}$, Nitra $^{\mathrm{a}, \mathrm{b}}$, Pezinok $^{\mathrm{a}}$, Slanec $^{\mathrm{a}}$, Šahy $^{\mathrm{a}}$, Topolčianky ${ }^{\mathrm{b}}$, Trnava $^{\mathrm{a}}$, Trstice $^{\mathrm{a}}$, Trstín $^{\mathrm{b}}$, \\
\hline & & Velké Kostolany ${ }^{\mathrm{a}}$, Vieska nad Žitavou ${ }^{\mathrm{a}, \mathrm{b}}$, Zvolen $^{\mathrm{a}}$ \\
\hline & Phomopsis sp. (=Phyllosticta fraxinicola) & 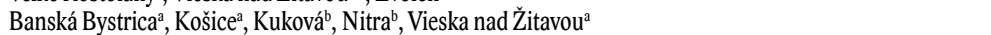 \\
\hline & Sordaria sp. & Trstice $^{c}$ \\
\hline & Trametes versicolor & Pezinok $^{\mathrm{a}}$ \\
\hline & Tubercularia vulgaris & Spišské Vlachy ${ }^{b}$, Trstice $^{b}$ \\
\hline & Xylaria longipes & Považský Inovec ${ }^{\mathrm{b}}$ \\
\hline \multirow{4}{*}{ Fornus } & Gloeosporidiella turgida & Bratislava $^{a}$ \\
\hline & Hymenoscyphus fraxineus & Vieska nad Žitavou ${ }^{\mathrm{b}}$ \\
\hline & Neonectria ditissima (=Nectria galligena) & Bratislava $^{a}$ \\
\hline & Phyllactinia fraxini & Bratislava ${ }^{a, b}$, Martin $^{a}$ Nitra ${ }^{a, b}$ Velký Krtíša \\
\hline
\end{tabular}




\section{Discussion}

The results show that the mycobiota associated with ash trees in Slovakia are very rich in species diversity. In previous papers (Juhásová et al. 2003, 2004), 10 fungal taxa on ashes growing in urban greenery have been recorded. Twenty-three other fungal taxa on ashes growing in five different types of stands were recorded in the present paper. Representative material of previously published findings of some fungi on ashes from Slovakia, Cercospora fraxini Ellis \& Kellerm., Gibberella baccata (anamorphic stage of Fusarium lateritium Nees) and Mycosphaerella fraxini (Niessl) Lindau (Juhásová et al. 2003, 2004) were not preserved. We did not record any wood-decaying fungi on the ashes examined from 2013 to 2017. The only herbarium specimen, Trametes versicolor, on F. excelsior is stored in NR herbarium. Ganoderma adspersum (Schulzer) Donk, G. applanatum (Pers.) Pat. (=G. lipsiense (Batsch) G.F.Atk.), G. carnosum Pat., and G. pfeifferi Bres. have been recorded on Fraxinus spp. in Slovakia (Juhásová et al. 2003; Gašparcová et al. 2017). The basidiomycete Inonotus hispidus (Bull.) P. Karst. causes an intense white rot and ash wood degradation in Slovak forests (Zúbrik et al. 2017). Longauerová et al. (2013) recorded an occurrence of Armillaria cepistipes Velen. and $A$. gallica Marxm. \& Romagn. on trees weakened by $H$. fraxineus. Wilt disease caused by Verticillium dahliae Kleb. and leaf blotch caused by Kabatiella apocrypta (Ellis \& Everh.) Arx, responsible for the mortality of ash trees in nurseries in Germany (Schröder \& Dujesiefken 2001), were not recorded in Slovakia. In our study, we noticed a rare occurrence of the fungus Discula fraxinea that causes anthracnose disease of ashes, premature leaf abscission, and the defoliation and disfigurement of infected branches in North America (Jacobs \& Danielson 2002).

In an extensive study of the mycobiota in declining ashes in Polish forests, Kowalski et al. (2016) identified more than 70 fungal taxa on stems and twigs in initial and advanced stages of dieback. They recorded $H$. fraxineus in almost $60 \%$ of the samples analysed, as well as the following frequently occurring fungi: Alternaria alternata, Diaporthe eres, Diplodia mutila (Fr.) Mont., Fusarium avenaceum (Fr.) Sacc., F. lateritium, and Phomopsis spp. Griffith \& Boddy (1988) recorded the species Phomopsis platanoidis (Cooke) Died., Libertella fraxinea Oganova, Peniophora lycii (Pers.) Höhn. \& Litsch., F. lateritium and Acremonium sp. on dead branches in ash crowns. Bakys et al. (2009) confirmed the pathogenicity in four of 24 isolated fungal species and reported symptomatic necrosis of the bark and cambium were caused by $A$. alternata, Epicoccum nigrum Link, Chalara fraxinea and Phomopsis sp. Przybyl (2002) observed the necrosis of the tissue on young Fraxinus seedlings inoculated with Diplodia mutila and F. solani (Mart.) Sacc. Diplodia fraxini, which we isolated from $F$. angustifolia and $F$. excelsior collected from five localities in Slovakia, is a species belonging to the Diplodia species complex associated with cankers and branch dieback on Fraxinus spp. in Europe. Alves et al. (2014) recorded D. mutila, D. pseudoseriata C.A. Pérez, Blanchette, Slippers \& M.J. Wingf., D. seriata De Not., D. subglobosa A.J.L. Phillips, Deidda \& Linald. and D. fraxini on all three native Fraxinus species. In the taxonomic revision of the genus Phyllosticta, van der Aa \& Vanev (2002) re-examined the material previously published as Phyllosticta fraxini Ellis \& G. Martin and Phyllosticta fraxinicola on Fraxinus spp. and designated the taxa as Phomopsis sp., the anamorphic stage of Diaporthe eres. The pathogenicity of Phomopsis controversa (Desm.) Traverso and P. scobina Höhn. isolated from necrotic ash shoots have not been confirmed (Przybyl 2002).

Powdery mildew disease caused by Phyllactinia fraxini occurs commonly on all three native species of Fraxinus in Slovakia (Table 2). Paulech (1995) recorded $P$. fraxini also on $F$. americana (Hurbanovo, Sesíleš, park). An Asian powdery mildew fungus, Erysiphe salmonii (Syd. \& P. Syd.) U. Braun \& S. Takam., recently introduced to Europe and found on $F$. excelsior and $F$. pennsylvanica in Ukraine (Heluta et al. 2017), was not recorded in our country until now.

Diverse forests can contribute to reduced susceptibility of trees to disease and fungal infection, and a subsequent increase in plant survival and growth (Keesing et al. 2006; Hantsch et al. 2014). According to Keesing et al. (2006), non-host trees can reduce fungal disease risks. When the density of these heterospecific trees increases, the proportion of host trees then becomes diluted in mixed stands. Our results showed a richer diversity of fungal taxa in seed orchards (monoculture plots) and both single-tree species and mixed-tree species forest plots. The invasive pathogenic fungus, $H$. fraxineus, caused devastating damage to the ashes growing in forests, seed orchards and tree alleys. We assume that very sporadic findings of $H$. fraxineus in urban ash plantations are a consequence of the quality of maintenance of urban greenery. The presence of the pathogen confirmed in seeds of $F$. excelsior (Cleary et al. 2013) is of great concern to phytosanitary protection authorities in countries outside the current zone of infestation.

Ash with extensive dieback symptoms rarely recovers under field conditions. There is very low proportion of trees tolerating infection by $H$. fraxineus in current common ash populations. Clonal seed orchards composed of dieback-tolerant clones appear to be the most efficient tool for management of ash dieback. The results of experiments on the selection and testing of candidate hyposensitive clones for new ash seed orchards are only preliminary (Longauerová et al. 2017). There have been early steps in propagating and screening a wide range of Fraxinus species and selection of tolerant $F$. excelsior genotypes for a new breeding program (Clark \& Webber 2017). There is currently no information on an effective control method for $H$. fraxineus. The maintenance of 
high tree vigor using cultural practices such as destroying fallen diseased leaves, pruning out dead branches and covering wounds with fungicide-augmented dressings is recommended.

\section{Conclusion}

The results of species diversity of fungi colonizing three native Fraxinus species in Slovakia are presented. A rich diversity of fungi on ashes represents a total of 30 fungal taxa. Although numerous fungi occur in necrotic ash tissue, only a few taxa are very frequent. Some of plant pathogenic fungi that are present in the stand of dead ashes may represent a noticeable threat to young or stressed and weakened ash trees. Other tree species may also be at risk of disease since these pathogenic fungi possess broad host spectrums. We assume other species of pathogenic fungi could also be present in dying ashes and thus contribute to dieback. Further mycological surveys are needed to identify fungal species that benefit from the initial infection by $H$. fraxineus or contribute to progress of ash dieback disease.

\section{Acknowledgements}

The authors thank Radovan Ostrovský (Institute of Forest Ecology SAS, Nitra, Slovakia) for creating a map, Gretchen M. Freed (Washington State University, Pullman, WA, USA) for kindly correcting the English, and the anonymous reviewers for valuable comments, which helped to improve the manuscript. This work was supported by the Scientific Grant Agency of the Ministry of Education and the Slovak Academy of Sciences, projects VEGA No. 2/0071/14 and No. VEGA 2/0062/18.

\section{References}

Aa, H. A. van der, Vanev, S., 2002: A revision of the species described in Phyllosticta. Utrecht, CBS, 510 p.

Adamčíková, K., Kádasi-Horáková, M., Jankovský, L., Havrdová, L., 2015: Identification of Hymenoscyphus fraxineus, the causal agent of ash dieback in Slovakia. Biologia, 70:559-564.

Alves, A., Linaldeddu, B. T., Deidda, A., Scanu, B., Phillips, A. J. L., 2014: The complex of Diplodia species associated with Fraxinus and some other woody hosts in Italy and Portugal. Fungal Diversity, 67:143-156.

Anonymous, 2015: Súhrnné informácie o stave lesov SR 2006-2014. Zvolen, NLC, 130 p.

Arx, J. A., Müller, E., 1954: Die Gattungen der amerosporen Pyrenomycetes. Beiträge zur Kryptogamenflora der Schweiz, 11:1-454.

Bakys, R., Vasaitis, R., Barklund, P., Thomsen, I. M., Stenlid, J., 2009: Occurrence and pathogenicity of fungi in necrotic and non-symptomatic shoots of declining common ash (Fraxinus excelsior) in Sweden. European Journal of Forest Research, 128:5160.
Clark, J., Webber, J., 2017: The ash resource and the response to ash dieback in Great Britain. In:Vasaitis, R., Enderle, R. (eds.): Dieback of European ash (Fraxinus spp.): consequences and guidelines for sustainable management. Uppsala, SLU Service/ Repro, p. 228-237.

Cleary, M. R., Arhipova, N., Gaitnieks, T., Stenlid, J., Vasaitis, R., 2013: Natural infection of Fraxinus excelsior seeds by Chalara fraxinea. Forest Pathology, 43:83-85.

Dennis, R. W. G., 1978: British ascomycetes. Lehre, J. Cramer, $456 \mathrm{p}$.

Drenkhan, R., Hanso, M., 2010: New host species for Chalara fraxinea. New Disease Reports, 22:16.

Ellis, M. B., Ellis, J. P., 1985: Microfungi on land plants. An identification handbook. London \& Sydney, Croom Helm, 818 p.

Gašparcová, T., Gáper, J., Gáperová, S., 2017: Väzba lesklokôroviek na druhy drevín na Slovensku. In: Sitková,Z., Pavlenda, P. (eds.): Dlhodobý ekologický výskum a monitoring lesov: súčasné poznatky a výzvy do budúcnosti. Zvolen, NLC, p. 49-53.

Griffith, G. S., Boddy, L., 1988: Fungal communities in attached ash (Fraxinus excelsior) twigs. Transactions of the British Mycological Society, 91:599-606.

Gross, A., Han, J.G., 2015: Hymenoscyphusfraxineus and two new Hymenoscyphus species identified in Korea. Mycological Progress, 14:1-13.

Hantsch, L., Bien, S., Radatz, S., Braun, U., Auge, H., Bruelheide, H., 2014: Tree diversity and the role of non-host neighbour tree species in reducing fungal pathogen infestation. Journal of Ecology, 102:16731687.

Heluta, V. P., Takamatsu, S., Siahaan, S. A. S., 2017: Erysiphe salmonii (Erysiphales, Ascomycota), another East Asian powdery mildew fungus introduced to Ukraine. Ukrainskyj BotaničnyjŽurnal, 74:212-219.

Jacobs, K., Danielson, D., 2002: Variation in field susceptibility of native and exotic ash species to anthracnose. Journal of Arboriculture, 28:35-40.

Juhásová, G., Ivanová, H., Bernadovičová, S., Kobza, M., Adamčíková, K., 2003: The most serious fungal pathogens on woody plants in urban greenery evaluated on an example - Pezinok. Folia Oecologica, 30:239-244.

Juhásová, G., Adamčíková, K., Bernadovičová, S., Ivanová, H., Kobza, M., 2004: Results of phytopathological and mycological survey of park woody plants in Institute of Social Welfare in Klasov. Acta Fytotechnica et Zootechnica, 7:110-113.

Kádasi-Horáková, M., Adamčíková, K., Pastirčáková, K., Longauerová, V., Malová, M., 2017: Natural infection of Fraxinus angustifolia by Hymenoscyphus fraxineus in Slovakia. Baltic Forestry, 23:52-55.

Keesing, F., Holt, R. D., Ostfeld, R. S., 2006: Effects of species diversity on disease risk. Ecology Letters, 9:485-498. 
Kiffer, E., Morelet, M., 2000: The Deuteromycetes - mitosporic fungi: classification and generic keys. Enfield, Science Publishers, 273 p.

Kirisits, T., Schwanda, K., 2015: First definite report of natural infection of Fraxinus ornus by Hymenoscyphus fraxineus. Forest Pathology, 45:430-432.

Kowalski, T., Czekaj, A., 2010: Symptomy chorobowe i grzyby na zamierających jesionach (Fraxinus excelsior L.) w drzewostanach Nadleśnictwa Staszów. Leśne Prace Badawcze, 71:357-368.

Kowalski, T., Łukomska, A., 2005: Badania nad zamieraniem jesionu (Fraxinus excelsior L.) w drzewostanach Nadleśnictwa Włoszczowa. Acta Agrobotanica, 58:429-440.

Kowalski, T., Kraj, W., Bednarz, B., 2016: Fungi on stems and twigs in initial and advanced stages of dieback of European ash (Fraxinus excelsior) in Poland. European Journal of Forest Research, 135:565-579.

Kunca, A. et al., 2006: Výskyt škodlivých činitel'ov v lesoch Slovenska za rok 2005 a ich prognóza na rok 2006. Zvolen, NLC, 89 p.

Lizoň, P., Bacigálová, K., 1998: Huby. Fungi. In: Marhold, K., Hindák, F. (eds.): Checklist of non-vascular and vascular plants of Slovakia. Bratislava, Veda, p. 101-227.

Longauerová, V., Mal'ová, M., Kunca, A., Leontovyč, R., 2013: Poznatky z hynutia jaseňov spôsobovaného hubou Hymenoscyphus pseudoalbidus (ana. Chalara fraxinea). In: Kunca, A. (ed.): Aktuálne problémy v ochrane lesa 2013. Zvolen, NLC, p. 77-81.
Longauerová, V., Kunca, A., Longauer, R., Malová, M., Leontovyč, R., 2017: The ash and ash dieback in Slovakia. In: Vasaitis, R., Enderle, R. (eds.): Dieback of European ash (Fraxinus spp.): consequences and guidelines for sustainable management. Uppsala, SLU Service/Repro, p. 209-219.

Paulech, C., 1995: Huby múčnatkotvaré (Erysiphales). Flóra Slovenska X/1. Bratislava, Veda, 294 p.

Przybyl, K., 2002: Fungi associated with necrotic apical parts of Fraxinus excelsior shoots. Forest Pathology, 32:387-394.

Schröder, T., Dujesiefken, D., 2001: Typische Schadsymptome an Baumarten: Krankheiten und Schäden der Esche. AFZ-DerWald - Allgemeine Forst Zeitschrift fürWaldwirtschaft und Umweltvorsorge, 56:276-279.

Sivanesan, A., 1984: The bitunicate ascomycetes and their anamorphs. Vaduz, J. Cramer, 701 p.

Sutton, B. C., 1980: The Coelomycetes - Fungi imperfecti with pycnidia, acervuli and stromata. Kew, Commonwealth Mycological Institute, $696 \mathrm{p}$.

Vasaitis, R., Enderle, R., 2017: Dieback of European ash (Fraxinus spp.): consequences and guidelines for sustainable management. Report on European Cooperation in Science and Technology (COST) Action FP1103 FRAXBACK. Uppsala, SLU Service/ Repro, 300 p.

Zúbrik, M., Kunca, A., Galko, J., Vakula, J., Leontovyč, R., Gubka, A. et al., 2017: Jaseň - najčastejšie choroby a škodcovia jaseňa. Les \& Letokruhy, 7-8:32-33. 